УДК 621.38; 536.5

В.С. Детлінг, І.В. Мірошниченко, В.І. Павленко, В.О. Тихоход

\title{
ВИБІР ПАРАМЕТРІВ АДАПТИВНИХ СИСТЕМ ОБРОБКИ ЕКСПЕРИМЕНТАЛЬНИХ ДАНИХ
}

\begin{abstract}
Анотація: показано, що перспективним напрямом в розробці адаптивних систем обробки експериментальних даних $€$ інтегрування в них інформаційновимірювальних систем, а також, що оптимізація адаптивної системи обробки експериментальних даних зводиться до отримання аналітичної залежності для цільових функцій вимірювання, наприклад, для похибок вимірювань; знаходження співвідношень параметрів адаптивних систем при вирішення задач оптимізації; ухвалення рішення по одному з вибраних критеріїв.
\end{abstract}

Ключові слова: адаптація, система обробки експериментальних даних, інформаційно-вимірювальна система, оптимізація, випадкові процеси.

\section{Вступ}

По відношенню до технічних систем (ТC), якими називатимемо сукупність динамічно пов'язаних штучних компонентів, що утворюють цілісну внутрішню структуру і володіють зовнішньою цілеспрямованістю, термін “адаптація” вперше з'явився в теорії автоматичного керування, потім в радіотехніці і зв'язку, в гідроакустиці і інших галузях науки і техніки. Під адаптивними ТС (АДТС) розумілися такі, для яких було зручно застосовувати термін "адаптація", причому сам термін не вимагав додаткових роз'яснень. Дещо пізніше за його сталь визначати через терміни, що не підлягають уточненню, типу “навчання", “самонавчання", “ефективність” тощо, що не дуже сприяло проясненню ситуації. В широкому значенні адаптивність ТС - це здатність системи модифікувати себе або зовнішне середовище при зміні умов фрункціонування з метою компенсації (хоча б часткової) втрати ефективності фрункціонування [1].

Нами було визначено, що з технічної точки зору адаптація е одним із способів використання автоматизованої техніки, що приводять до появи якісно нової властивості у функціонуванні ТС. В техніці - це вищий ступінь автоматизації ТC, що характеризуеться не тільки наявністю зворотних зв'язків, але і обов'язковою наявністю у складі ТС пристроїв вимірювання і аналізу результатів цих вимірювань, наділяючи властивістю пам'яті і володіючих здатністю ухвалювати деякі рішення на основі аналітичних і формальних логічних висновків.

3 системної точки зору адаптація є процесом безперервної оптимізації, тому будь-яка АДТС повинна, принаймні, протягом деякого часу, підтримувати свою оптимальність.

3 математичної точки зору АДТС повинні вирішувати задачі стохастичної екстраполяції, тобто прогнозувати якість свого функціонування

(c) В.С. Детлінг, I.В. Мірошниченко, В.І. Павленко, В.О. Тихоход, 2012 
і підтримувати його на деякому заданому рівні (наприклад, верхньому) протягом наперед певного інтервалу часу.

Загальний принцип побудови адаптивних систем заснований на вимірюванні, тобто отриманні оцінок, відомих (або визначуваних в процесі роботи АДТС) інформативних параметрів, запам'ятовуванні цих оцінок і введення їх у вибраний фрункціонал обробки. При цьому практично завжди залишаеться нез'ясованою оптимальність всієї процедури в цілому, оскільки вид оцінки вибирається з позицій теорії вимірювань, що припускає отримання оцінок параметрів з деякою погрішністю, а функціонал обробки з позицій теорії перевірки гіпотез, що припускає наявність достатньо повної інформації про об’ект.

Розуміючи під оптимізацією досягнення якнайкращого результа-

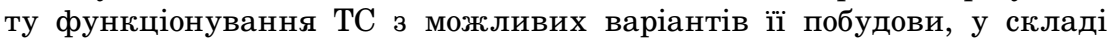
системи обробки експериментальних даних (СОЕД) на рівні системного аналізу розглянено вимірювальний блок (далі - інформаційновимірювальна система - IBC, інформаційно-вимірювальний комплекс IBК або вимірювально-обчислювальний комплекс - ВОК) та блок аналізу і ухвалення рішень [2].

3 теоретичної точки зору інформаційно-вимірювальний підхід гарантуе вимірність різних множин. Основою побудови теорії вимірювань повинне бути вивчення топологічних властивостей множин, причому міра топології вимірних множин повинна дозволити ввести амплітудний, просторовий і тимчасовий заходи процесу і прийти до поняття інформаційної продуктивності ознак, властивості яких відображаються у вигляді результатів вимірювань [3].

\section{Постановка задачі}

Розробити класифікацію адаптації у системах обробки експериментальних даних та інформаційно-вимірювальних системах; розробити загальні для всіх систем, їх вузлів і блоків, а також середовищ розповсюдження сигналів (носіїв інформації), методології вимірювання інформативних параметрів; отримати оцінки цих параметрів та оптимальне їх узгоджування.

\section{Основний зміст}

IBC (синоніми - IBK, ВОК) - багатоканальний і (або) багатофункціональний технічний пристрій, призначений для вимірювань і є сукупністю засобів вимірювань (ЗВ) - вимірювальних приладів (ВП), первинних і вторинних вимірювальних перетворювачів (ПВП і ВВП), з'єднаних загальним алгоритмом функціонування і призначену для отримання даних про стани об'екту шляхом деяких перетворень безлічі фізичних величин, розподілених в часі і в просторі.

Якщо результатом перетворень є іменоване число $[N]=n \Delta x$, яке має розмірність $x$ і отримане як результат рахунку $n$ одиниць вимірювання $\Delta x$, то таке перетворення називається вимірюванням [3]; якщо логічні вислови типу “більше, рівно, менше" - то контролем. Звідси сліду- 
ють відмінності між IBC і системами автоматизованого контролю (тобто з участю людини-оператора) або автоматичного контролю (без участі оператора), часто що позначаються абревіатурою САК.

COEД, виконуючі всі основні функції IBC, мають додаткову можливість дії на об'єкт вимірювань з метою наближення до $E X T R\left\{\begin{array}{l}M A X \\ M I N\end{array}\right\}$ цільової функції експерименту (погрішності, надійності, витрат ресурсів і т.д.). В таких термінах задача оптимізації АДТС зводиться до послідовного рішення для обох блоків ТС трьох основних етапів:

- отриманню аналітичної залежності для цільових функцій (наприклад, для погрішностей вимірювань, що е визначальним показником якості для СОЕД і IBC);

- знаходженню математичних співвідношень для цілком певних задач оптимізації;

- ухвалення рішення по одному з вибраних (або спеціально розроблених) критеріїв.

Для оцінки ефективності будь-якої ТС необхідно передбачити сумісний аналіз ефекту від застосування ТС при виконанні сукупності умов, що реалізовують прийняті принципи і витрати на його досягнення. При цьому використовують технічні, економічні і техніко-економічні критерії ефективності ТC .

Технічні критерії (їх досить багато) зазвичай відображають технічний рівень ТС (тобто “досконалість” з погляду розробників) або ступінь придатності ТС для вирішення поставлених задач. Проте така оцінка носить односторонній характер і $є$ в більшості випадків недостатньою, за винятком тих, випадків, коли зняті економічні обмеження (наприклад, у військовій галузі, в космічних дослідженнях).

Економічні критерії (вартості витрат ресурсів), будучи більш загальними і універсальними, не відображають, в більшості випадків, технічної досконалості, з погляду розробників, і динаміки роботи ТС.

Техніко-економічні (комплексні) критерії переважатимуть в проектуванні, тому вимагають спроб фрормування таких критеріїв оцінки ефективності ТC, що представляють, наприклад для IBC, собою мінімум похибок при обмеженнях щодо ресурси.

Для більшості ТС можливі чотири види адаптації [1]:

- зовнішньо-зовнішня, коли ТС реагуе на зовнішні зміни модифікацією свого оточення (вимкнення, у тому числі і знищення, зовнішніх джерел перешкод; екранування, перенесення самої ТС в інше місце);

- зовнішньо-внутрішня, коли ТС реагуе на зовнішні зміни модифікацією самої себе (прикладом $е$ зміна структури оптимального приймача сигналів при зміні характеру перешкод), включаючи самоліквідацію;

- внутрішньо-зовнішня, при якій ТС реагуе на внутрішні зміни модифікацією свого оточення (включення зовнішніх джерел живлення при енергетичній адаптації, включення зовнішнього резерву при відмовах, а також прийоми дублювання і резервування тощо; 
- внутрішньо-внутрішня, коли ТС у відповідь на внутрішні зміни модифікує сама себе (наприклад, адаптивні приймачі з внутрішнім контуром адаптації).

Існування різних шляхів і методів зменшення похибок СОЕД і IBC викликано деякою відмінністю в підході до їх аналізу в теоріях вимірювань, надійності, перешкодозахисності (перешкодостійкості) і інших суміжних галузях науки і техніки [3].

Методи підвищення точності систем можна розбити на три основні групи, включаючи ті або інші принципи адаптації.

1. Усунення самих джерел похибок або їх знищення в місці виникнення. Прикладами можуть служити методи знищення індустріальних перешкод усередині цих джерел (екранування); зменшення внутрішніх шумів блоків і вузлів електронної апаратури при переході на досконалішу (або іншу) елементну базу; ослаблення взаємного впливу між каналами (тимчасове, просторове і інше розділення сигналів в каналах IBC); підвищення перешкодостійкості систем за рахунок переходу каналів зв'язку на складні і шумоподібні сигнали; перехід на нетрадиційні діапазони передачі і обробки сигналів (міліметрові хвилі, оптичні лінії), де рівень перешкод різко зменшуеться; термостабілізація і термоізоляція (зменшення тепловиділення); зменшення числа контактів шляхом застосування інтегральної технології; стабілізація джерел живлення, тощо.

2. Ослаблення дії джерел похибок в тих місцях системи, де дія їх максимальна. Сюди можна віднести застосування просторово-часової обробки сигналів в приймальних частинах IBC для зменшення впливу перешкод; застосування принципів компенсації, інваріантності і комплексірування вимірювань для зменшення апаратурної похибки; резервування апаратури і вбудований контроль для підвищення надійності [2], в тому числі і метрологічної; застосування принципу зворотнього зв'язку у всій IBC або їі частинах для зменшення погрішності вимірювань за рахунок зменшення внутрішніх нестабільностей, зменшення лінійних і нелінійних спотворень, знищення деяких видів перешкод тощо; термостатировання, екранування і інші види захисту від електричних, магнітних, акустичних і інших полів; тренування апаратури для виявлення відмов тощо.

3. Комбіновані методи, що дозволяють усунути одні джерела похибок і ослабити дію деяких інших джерел.

Одним з основних комбінованих методів дії е перехід від аналогової до цифрової обробки електричних сигналів, при якій усуваеться похибка від нелінійності, зменшуеться вплив нестабільності тракту передачі. Завдяки використанню інтегральних схем з великим рівнем інтеграції двійкових цифрових елементів з'являеться можливість реалізації більш перешкодостійких алгоритмів обробки (адаптивних, просторовочасової обробки, стохастичних ітераційних тощо) і розширяються можливості резервування апаратури за рахунок застосування типових елементів заміни (ТЕЗ). 
Проте, разом із застосуванням ряду специфічних для цифрової обробки ефективних алгоритмів, що підвищують сумарну точність $\delta_{\Sigma}$ СОЭД, з'являються нові джерела похибок, наприклад, похибки від квантування і похибки алгоритмів. Проте при цьому розширяеться смуга частот каналів зв'язку в IBC, що може усилити вплив інших похибок, наприклад, від кінцевої швидкості виконання операцій на ЕОМ. Але в більшості випадків аналого-цифрова обробка дає можливість підвищити “узагальнену точність“ $E T=1 / \delta_{\Sigma}$ (exactitude $-E T$ ) COEД і IBC [1], де $\delta_{\Sigma}-$ сумарна відносна похибка.

Більшість об'єктів і сигналів при вимірюваннях параметрів траєкторій рухомих об'ектів в геоцентричній або геліоцентричній системах координат, сейсмології при локалізації наземних і підземних аномалій, радіолокації, гідрографії і гідроакустиці, фізичному моделюванні в авіації і космонавтиці (продування моделей в аеродинамічних трубах тощо описуеться моделями імовірності. В основі експериментальних досліджень в цих галузях частіше за все лежить отримання оцінок характеристик імовірності випадкових процесів, тобто статистичні вимірювання параметрів сигналів. Якщо інформація про досліджувані процеси обмежена, то виникає необхідність в адаптації (у широкому значенні), оскільки наперед практично неможливо оптимізувати структуру системи вимірювання і обробки сигналів, або, інакше кажучи, задати кількість і вид статистичних характеристик.

В інформаційно-вимірювальній техніці в даний час отримали розвиток, разом з традиційними, так звані структурні методи підвищення точності [5], що використовують зовнішньо-внутрішню адаптацію.

При відомій структурі ТС і заданому алгоритмі обробки сигналів на етапі проектування IBC, приймаючи за визначальний показник якості похибку вимірювання певної характеристики, можна сформулювати вимоги до одного каналу IBC як до засобу вимірювання (ЗВ), що містить вимірювальний перетворювач (ВП), який проводить процедуру вимірювання і отримання результатів вимірювання у вигляді іменованого числа одиниць вимірювання і спеціалізованої аналогової (електронній, оптичної тощо) або цифрової EOM (host computer), що виконуе оптимальну, по обраному або заданому критеріях, обробку вихідних сигналів ВП на фоноі перешкод.

Таким чином в IBC, на відміну від систем автоматичного керування (САК), дійсні значення вхідного сигналу невідомі i, отже, не можуть бути оцінений так швидко, як виробляеться “помилка розузгодження", що є основою для побудови САК. В IBC принципово неможливо охопити зворотним зв'язком первинні ВП, яки є основними джерелами нестабільності характеристик. Тому при проектуванні СОЕД і IBC різного рівня, у тому числі і адаптивних, необхідно враховувати наступні основні принципи:

- застосування інформаційних критеріїв ефективності адаптації;

- облік ступеня апріорної невизначеності умов роботи;

- використання статистичних методів імовірності; 
- використання формалізованого опису підсистем IBC.

Звичайно, в таких випадках говорять про задачу статистичного синтезу з повною апріорною інформацією про вхідні сигнали, тобто коли густина імовірності сигналу і перешкоди відома. Якщо ж густина імовірності або деякі їх параметри невідома, то прийнято говорити про задачі статистичного синтезу в умовах апріорної невизначеності, причому слід завжди мати на увазі, що за відсутності апріорних відомостей про сигнали і перешкоди рішення задачі синтезу оптимальної системи неможливе у принципі. Проте на практиці завжди є деякі дані, засновані на попередньому досвіді, інтуїції або фрізичному трактуванні задачі. 3 погляду інформатики фрізичне трактування задачі і інтуїція належать до ключових задач моделювання, а задача отримання апріорних даних - до задач формування баз знань у визначеному розділу науки і техніки, що надалі називатимемо проблемним ареалом - Problem area (PRAR).

Зрештою можна говорити про розробку інформаційного забезпечення (I3) і математичного (MЗ) забезпечення системи автоматизованого проектування (CAПР) у визначеній PRAR (наприклад, при вимірюваннях параметрів шорсткості в машинобудуванні, хвилястості поверхні в авіабудуванні тощо) і принципів адаптації алгоритмів роботи COEД і IBC. Вважаючи, що адаптивна IBC може пристосовуватися до зміни умов, модифрікуючи свою структуру, кращі результати отримають при здійсненні спрямованого перебору варіантів структур, що спирається на певні знання, причому більш досконалі системи спираються на велику базу знань.

Перший рівень самовдосконалення будь-якої автоматизованої адаптивної COEД завжди орієнтований тільки на конкретну PRAR (наприклад, експертні системи), а алгоритм роботи системи представлено фріксованими програмами обробки. Саме програма обробки є основним інваріантом однорівневої адаптивної СОЕД, оскільки такі системи пристосовуються до поточних вхідних дій і поточного стану своєї бази знань.

Другий рівень самовдосконалення автоматизованої адаптивної СОЕД повинен дати можливість змінювати програму основної обробки i відповідну частину бази знань, часто звану умовно-постійною інформацією (класифікатори і тезауруси), при зміні умов функціонування. Основними інваріантами дворівневої адаптивної СОЕД вважаються критерії ефективності, програми оптимізації (наприклад, для IBC - методи підвищення точності) і фріксовані набори модулів (I3, M3 і багатофункціональні елементи), з яких можуть збиратися адаптивні IBC різної архітектури. До цього типу дворівневих СОЕД відноситься більшість сучасних адаптивних СОЕД [1].

В процесі проектування число ефективних ідей убуває приблизно по експоненціальному закону при одночасному непрогнозованому зростанні витрат, причому може виявитися, що за час проектування певна ідея до моменту закінчення проектування і випробувань застаріє. Тому реалізація оптимізації, в даному випадку по критерію “зменшення часу 
проектування", є необхідностью. Проте використання методів оптимізації в "чистому вигляді"для задач проектування СОЕД ускладнено через нечітку постановку задачі і майже завжди потрібна розробка специфічного для даної PRAR підходу.

Класична задача оптимізації полягае в знаходженні екстремального значення деякої функції $f\left(S_{1}, S_{2}, \ldots S_{K}\right)$ у визначеній прийнятим чином області, що задається нерівностями вигляду $G$ або $G\left(S_{1}, S_{2}, \ldots S_{K}\right) \leqslant 0$.

Для вирішення цієї задачі застосовуеться багато методів: лінійне, нелінійне, динамічне, дискретне, опукле квадратичне (або стохастичне) програмування з різними підходами до обліку діючих обмежень (симплекс-метод Данцига; класичні методи варіаційного числення - рівняння Ейлера-Лагранжа; градіентні методи - принцип оптимальності Р. Беллмана; принцип максимуму Понтрягина і інші методи). Вибір підходу залежить від вибору цільової функції і характеру обмежень, що припускає дослідження самої постановки на коректність.

Визначення коректності можна представити у вигляді $z=R(u)$, де $z$ - рішення кількісної задачі за початковими даними, $z \mathrm{i} u \mathrm{e}$ елементи метричних просторів $Z$ i $U$ з відстанями між елементами $\rho_{u}\left(u_{1} u_{2}\right)$ i $\rho_{z}\left(z_{1} z_{2}\right), u_{1} u_{2} \in U, z_{1} z_{2}$, при виконанні двох умов.

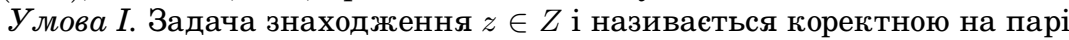
метричних просторів і, якщо:

- визначено поняття рішення по $u$, тобто відомо, який результат і в якій формі бажано його отримати;

- $\mathbf{e}$ множину $u=\left\{u_{i}\right\}, i=\overline{1, N}$ таке, що для всякого $u \in U \mathbf{e} z \in Z$;

$-\operatorname{rank}(u)=z$, тобто рішення однозначно; II.

- задача стійка на просторі рішень $z=R(u)$, тобто виконується умова

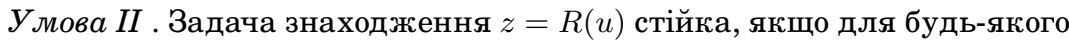
числа існуе таке, що з витікає

де $z_{1}=R\left(u_{1}\right) ; z_{2}=R\left(u_{2}\right) ; u_{1} u_{2} \in U ; z_{1} z_{2} \in Z$.

Порушення хоча б одного з пунктів цих умов свідчить про некоректність задачі.

Задачі оптимізації більшості СОЕД некоректні майже по всіх пунктах, тому для прикладних задач математиками (А.Н. Колмогоровим, А.Н. Тіхоновим, А.А. Самарою, М.І. Лаврентьевим, Г.И. Марчуком тощо) були розроблені методи глобальної регуляризації слабо коректних і некоректних задач: метод регуляризації А.Н. Тіхонова; методи регуляризації задач лінійного програмування на принципі інваріантності оптимальних рішень; методи регуляризації задач дискретного програмування, наприклад, метод “равильних" відсікань (алгоритм Гоморі), тощо.

Умова регуляризації задач великої розмірності $m * n$, де $m-$ число невідомих при $n$ обмеженнях, типовим зразком яких е задача оптимізаціï IBC в будь-якім PRAR, може бути сформульовано як умова застосування покрокової оптимізації - субоптимізації, яка має універсальний характер і $є$ керівним правилом при оптимізації різних багатоступінчатих ієрархічних структур і тому часто породжує дію аналогічних прийо- 
мів: декомпозиції, іерархічності, модульності тощо. Наприклад, в адаптивних СОЕД визначальним показником якості є сумарна відносна похибка $\delta_{\Sigma}$ вимірювань, витрати на досягнення якої вступають в суперечність з цінністю, звичайно що зменшуеться з часом.

Звернув увагу те, що оптимальне рішення обов'язково повинне лежати в області компромісів і, враховуючи рекомендації до вибору показників якості $Q$ АДТС, по науковому обгрунтовуванню рішень і методів проектування, при наявності яких вимоги надійності, у тому числі і метрологічної, $є$ обов'язковими, а також про першорядне значення для більшості СОЕД інформаційної цінності, приходимо до необхідності уточнення процедури фрормування показника $Q$.

Фізичному сутність процесу формування показника якості базуеться на принципі порівняння з еталоном, для якого відомі або сформульовані на стадії зовнішнього проектування основні і оптимальні в певному значенні показники $Q_{0}=\left\langle Q_{01}, Q_{02}, \ldots, Q_{0 N}\right\rangle$. При оптимізації досягаеться мінімум відстані $\rho\left(Q_{1} Q_{2}\right)$ між кінцями $n$ - мерных векторів показників, що визначаються безліччю показників $Q_{0}$ еталонної і $Q_{1}$ проектованої системи

$$
\left.M I N \rho\left(Q_{1} Q_{2}\right)=M I N \sqrt{\alpha_{1}\left(Q_{1}-Q_{01}\right)^{2}+\ldots+\alpha_{N}\left(Q_{N}-Q_{0 N}\right)^{2}}\right)^{2},
$$

де $\alpha_{1} \alpha_{2} \ldots \alpha_{N}$ - вагові коефіціенти, вибирані так, що $\sum_{i=1}^{n} \alpha_{i}=1$.

Параметрична чутливість $S$ відстані $\rho\left(Q_{1} Q_{2}\right)$ до змін будь-кого $Q_{i} \in Q=\left\langle Q_{1}, Q_{2} \ldots Q_{n}\right\rangle, i=\overline{1, n}$ характеризуеться співвідношенням

$$
S_{Q_{1}}^{\rho}=\frac{Q_{1}}{\rho\left(Q_{1} Q_{0}\right)} \frac{d \rho\left(Q_{1} Q_{0}\right)}{d Q_{1}}=\alpha_{i} Q_{1}\left(Q_{1}-Q_{0}\right), i=\overline{1, n},
$$

з якого виходить умова вибору найістотніших для заданого показника якості параметрів, що забезпечують $S_{Q_{1}}^{\rho}=M A X$.

Комплексний показник якості повинен відображати вирішення головних і принципових для СОЕД компромісів:

- між цінністю $V$ інформації і витратами $C$ на отримання даних (результатів вимірювання, контролю тощо), що досягають однієї з основних метрологічних характеристик СОЕД - похибки $\delta_{\Sigma}$ (Рис. 1)

- між витратами $E$ на експлуатацію СОЕД і початковими витратами $P$ при зміні параметрів системи (наприклад, надійності $R$ ) (Рис. 2).

Досягнення першого компромісу (Рис. 1) припускае досягнення $M A X[V(\delta)-C(\delta)]$, а другого компромісу - досягнення мінімуму сумарних витрат ресурсів $F_{\Sigma}=M I N F_{\Sigma}$ (Рис. 2). Різниця між $R_{\min }$ i $R_{o p t}$ видна з побудов, відображених на Рис. 2.

Звідси витікае, що показник якості адаптивної СОЕД повинен бути складеним і комплексним, тобто відображати техніко-економічні (витратні) аспекти всього життевого циклу системи.

Комплексний показник якості COEД або IBC може бути приведений в адитивній фермі при забезпеченні в процесі оптимізації наступних умов: 


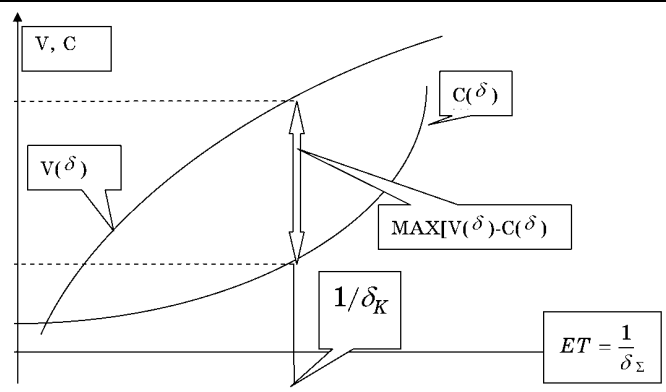

Рис. 1 - Перший компроміс мів витратами $C$ на отримання даних і цінністю $V$ інформації

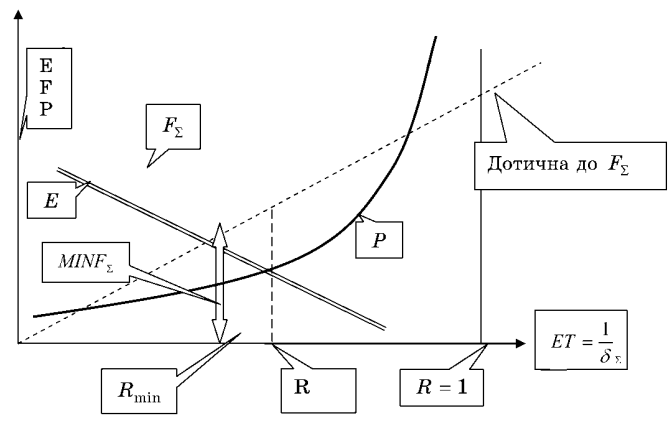

Рис. 2 - Другий компроміс $-F_{\sigma}=M I N F_{\sigma}$ сумарних витрат ресурсів

$$
Q_{1}=\beta_{1} F_{1}+\beta_{2} F_{2}, M A X F_{1}=M A X[V(\delta)-C(\beta)], M A X F_{2}=M I N F_{\Sigma},
$$

де $\beta_{1}+\beta_{2}=1$ - вагові коефіціенти.

Спільність властивостей даного комплексного показника якості системи відображається за допомогою понятів цінності $V$ інформації і витрат $E$ на їі отримання і обробку.

Цінність інформації є основним критерієм для СОЕД і включає наступні чинники: похибка (точність) вимірювання IBC, інтегрованої у склад COEД; давність інорормації про стан об'єкту (час отримання результатів і узгодженням їх з параметрами об'єкту); давність інформації для вироблення рішення (керуючої дії); можливість прогнозування (інакше кажучи, можливість проведення адаптаціі); доцільність і післядія.

Проектування адаптивних СОЕД третього рівня самоорганізації в більшості випадків зводиться до проектування якоїсь дворівневої адаптивної СОЕД, де інваріантами є вже метакритерії (критерії більш високого рангу, наприклад, етичні або естетичні). Початковими даними в цих СОЕД е інформація про зовнішню обстановку і можливі внутрішні стани всієї безлічі проектованих СОЕД нижніх рівнів. До такого 
роду систем відносяться так звані “інтелектуальні” і деякі інші СОЕД, що спираються в своїй роботі на бази знань, що постійно обновляються, наприклад, активні (локаційні) і пасивні системи виявлення і класифікації, системи глобального позиціонування (GPS) та інші.

Відомо, що адаптивна СОЕД є діалоговою системою, в якій діалог будуеться на аналізі інформації, отриманої в результаті рішення строго формалізованих задач на основі методів математичного моделювання. Для кожного класу проектованих систем змістовна сторона процедури опису (формалізації) має свою специфіку і у багатьох випадках, наприклад в медицині, унікальна. Ця теза дає підстави вважати, що неможливе створення універсальної адаптивної СОЕД, інваріантної до PRAR. Аналогічним є становище і з розробкою експертних систем, оскільки доведено, що універсальні методи ефективні в обмежених випадках. Проте, основні принципи побудови, як експертних систем, так і СОЕД різного призначення, швидше за все, едині і можуть бути використані при їх проектуванні.

Таким чином, будь-яка адаптивна технічна система повинна безперервно вирішувати оптимізаційні задачі, або, інакше кажучи, вирішувати задачі стохастичної екстраполяції (прогнозу) випадкових процесів. Методи статистичного прогнозу випадкових процесів. дозволяють оцінювати майбутні значення за наслідками вимірювання минулих і поточних значень заданих характеристик імовірності. До найточніших, хоча і достатньо громіздким, способам прогнозування відносяться сучасні методи моделювання, в першу чергу імітаційного моделювання на EOM [4]. Передбачені тим або іншим способом значення інформативних параметрів є початковими даними для вироблення або керівної дії, або для ухвалення рішення.

Наприклад, в системах автоматичного керування (CAK), процес перетворення цих даних в керівну дію складається з ряду математичних і логічних операцій, виконуваних аналоговими або цифровими процесорами. При цьому однією з найважливіших задач є розробка ефективних алгоритмів функціонування процесора при заданих (або вибраних) параметрах, наприклад, точності, швидкодії тощо. Тобто завжди треба мати на увазі, що у складі будь-якої системи керування завжди є блок (вузол, пристрій) вимірювання сигналу розузгодження, що має структуру адаптованої IBC.

\section{Висновки}

Для систем обробки експериментальних даних та інформаційновимірювальних систем розглянуто кілька видів адаптації для уніфікованого каналу вимірювання шорсткості, що може бути перспективним напрямом при оптимізації адаптивних автоматизованих систем, які проектуються.

1. Розроблено класифрікацію видів адаптації СОЕД для уніфікованого каналу вимірювання шорсткості. 
2. Показано, що перспективним напрямом в розробці адаптивних СОЕД є інтегрування в них інформаційно-вимірювальних систем.

3. Показано, що найдоцільнішими видами адаптації СОЕД являється зовнішньо-внутрішня адаптація, типовим прикладом якої є структурні методи підвищення точності, а також внутрішньовнутрішня адаптація.

4. Показано, що оптимізація адаптивної СОЕД зводиться до отримання аналітичної залежності для цільових функцій вимірювання, наприклад, для похибок вимірювань; знаходження співвідношень параметрів адаптивних систем при вирішення задач оптимізації; ухвалення рішення по одному з вибраних критеріїв якості системи.

5. Розроблена методологія формування визначального показника якості, яким для СОЕД є сумарна похибка вимірювання оцінок інформативних параметрів.

6. В адитивній формі сформовано комплексний показник якості адаптивних систем, який відображає вирішення головних і принципових для СОЕД компромісів між цінністю інформації та витратами на їі отримання і обробку, а також показник якості між витратами на експлуатацію і початковими витратами на зовнішне проектування СОЕД.

\section{Література}

1. Детлинг В.С, Мирошниченко И. В. Выбор вида адаптации в информационных системах // V Международная научно-техническая конференция "Гиротехнологии, навигация и управление движением" - Сборник докладов, Киев 21-22 апреля 2005 г. - с. 310-313

2. Детлинг В.С., Мирошниченко И.В. Обеспечение надежности многоуровневых автоматизированных систем // VI Международная научно-техническая конференция "Гиротехнологии, навигация и управление движением” - Сборник докладов, Киев 24-25 апреля 2007 г. - c. $310-313$

3. Дорожовець М., Мотало В., Стадник Б. Основи метрології та вимірювальної техніки. У двох томах. Том 1. Основи метрології, Львів, вид. “Львівська політехніка, 2005.

4. Поноларенко B.К., Мирошниченко В.С. Выбор параметров измерителей числовых характеристик случайных процессов, Известия ВУЗ СССР, разд. Радиоэлектроника, XVI, 1971, 7.

5. Туз Ю.М. Структурные методы повышения точности измерительных устройств. - К.: Вища школа, 1976.- 256 с.

Отримано 16.02.2012 p. 